This column is being written as National Library Week begins, and it caps a month of intense activity by ALA to capture media attention and stimulate public interest in all types of libraries at a time of potential threats to the right to know from library budget cuts, censorship, illiteracy, and restricted access to public information. Here are a few highlights of ALA efforts with a Washington spin.

\section{Fol Day}

National Public Radio's Nina Totenberg, C-SPAN founder Brian Lamb, and National Security Archive founder Scott Armstrong received the James Madison Award sponsored by the Coalition on Government Information (COGD). At a reception on March 16, Freedom of Information Day and Madison's birth date, COGI chair Nancy Kranich (New York University Libraries) presented the awards before about 100 observers. The annual awards honor those who have championed, protected, and promoted public access to government information and the public's right to know. ALA founded the 50-member COGI in 1986.

\section{Less Access}

An indexed compilation of the semiannual updates of Less Access to Less Information By and About the U.S. Government was released by ALA on Freedom of Information Day, March 16. Less Access, prepared by Anne Heanue of the ALA Washington Office, is an ongoing chronology documenting a decade-long erosion of public access to government information. The 239page 1988-1991 chronology is available for $\$ 10$ from the ALA Washington Office, 110 Maryland Ave., NE, Washington, DC 20002-5675. Orders must be prepaid and must include a self-addressed mailing label.

\section{Call for America's Libraries}

Freedom of Information Day, March 16, also marked the launch by ALA President Patricia Glass Schuman of ALA's "Call for America's Libraries" campaign. The month-long campaign offered Americans the opportunity to demonstrate their support for libraries, librarians, and the right to know by calling a toll-free number. Calls generated names of library supporters to be shared with congressional leaders in order to demonstrate public support for libraries.

\section{Library Legislative Day}

Preliminary results of the "Call" campaign were scheduled to be shared with congressional offices during the 18th annual Library Legislative Day on April 7 during National Library Week. Several hundred library supporters were gathering for an organized day of lobbying, with the emphasis on securing funding for federal library and related programs. The day's events, which include briefings and a congressional reception, are sponsored by ALA, the District of Columbia Library Association, and the Special Libraries Association. Plan to come next year on April 20, 1993!

\section{Fellowships available}

One concrete result of successful library community lobbying is the large number of library science fellowships available for the 1992-93 academic year. Congress increased funding for the Higher Education Act Title II-B library career training program - from $\$ 651,000$ in FY '91 to $\$ 5$ million in FY ' 92 - because of data showing shortages of librarians and library faculty.

The Library Programs Office of the Department of Education announced awards to 38 institutions of higher education to provide fellowships in library and information science. The 73 grants awarded under HEA II-B will support 300 master's, 12 post-master's, and 104 doctoral fellowships.

Awardee institutions will be able to provide a stipend to each fellowship student and an equal amount to the university to cover the cost of providing training and waiving tuition fees. Individuals interested in HEA II-B fellowships should apply directly to graduate programs in library and information science. For further information, call the ED Library Program office at (202) 219-1315.

Carol Henderson is deputy dinector of ALA's Washington Office, (202) 545-4440; Bitnet:NU_ALAWASH@CUA 